\title{
Ethnobotanical Survey of Plants Used as Memory Enhancer in Three States of Southwestern Nigeria
}

\author{
Olatunji Peter Babawale ${ }^{1,2^{*}}$, Fasola Remi Taiye ${ }^{2}$, Onasanwo Samuel Adetunji ${ }^{3}$ \\ ${ }^{1}$ Department of Biological Sciences, College of Science, Afe Babalola University, Ado Ekiti, Nigeria. ${ }^{2}$ Department of Botany, University of Ibadan, Oyo \\ State Nigeria. ${ }^{3}$ Department of Physiology, University of Ibadan, Oyo State, Nigeria.
}

\begin{tabular}{|c|c|}
\hline ARTICLE INFO & ABSTRACT \\
\hline Article history: & \multirow{9}{*}{$\begin{array}{l}\text { This study sought at documenting plants locally used for memory enhancement by the people of three States of } \\
\text { Southwestern Nigeria, predominantly inhabited by the Yoruba tribe. A combination of social survey, direct field } \\
\text { observations and semi structured questionnaires were administered among the local herb vendors, traditional } \\
\text { medicine practitioners (TMPs) and knowledgeable people in plant usage. A total number of } 260 \text { respondents } \\
\text { were interviewed across the States. The total populations of the respondents were made up of the herbalists } \\
\text { (32\%), herb sellers ( } 40 \% \text { ) and "other occupation" comprising students and artisans ( } 28 \% \text { ). The total population } \\
\text { consisted of } 55.4 \% \text { males and } 44.6 \% \text { females with ages ranging from } 10 \text { to } 75 \text { years. Thirty seven medicinal } \\
\text { plant species belonging to twenty eight families were gathered. Of all the plant species, Bacopa floribunda } \\
\text { (R.Br) Wettst and Scoparia dulcis L belonging to the same family Scrophulariaceae had the high ranked of } 40 \\
\text { and } 27 \text { respectively. A link between plant local names and their usage for memory enhancement was } \\
\text { established. }\end{array}$} \\
\hline 4/05/2016 & \\
\hline Revised on: & \\
\hline Acce & \\
\hline Available online: $26 / 09 / 2016$ & \\
\hline Key words: & \\
\hline Bacopa floribunda, Scoparia & \\
\hline dulcis, Scrophulariaceae, & \\
\hline $\begin{array}{l}\text { Memory enhancement, } \\
\text { Medicinal plants. }\end{array}$ & \\
\hline
\end{tabular}

\section{INTRODUCTION}

Traditional medicine is a combination of knowledge and practice, whether explicable or not, used in diagnosing, preventing and eliminating a physical, mental or social disease. It may rely exclusively on past experience and observation handed down from generation to generation verbally or in writing, otherwise known as herbalism, the ancient method of curing disease through the use of plant (Soladoye, 2010). Herbal medicine has been a significant element in the cultural patrimony which still remains the main recourse for a large majority of people for addressing health problems Lawal et al., 2014. In the modern day, the use of medicinal plants is gaining more recognition. However, in most developing countries; the knowledge on the use of these plant resources for medicine is vast disappearing due to lack or scanty documentation of this invaluable biological resource. In Nigeria, the documentation of indigenous knowledge on the use of plants for medicinal

* Corresponding Author

Email:walersm@yahoo.com purposes exists but, inadequate and almost lacking in some parts of the country (Elufioye et al., 2012). The use of medicinal plants for memory enhancing and anti-aging is popular among the Yoruba folk of western Nigeria. Local remedies for memory loss and aging are popularly referred to as "Ogun isoye and Ajidewe" respectively which is adopted sometimes used by man as food or in form of medicine which modify the functioning of the central nervous system (CNS) (Elufioye et al., 2012). Memory could be described as the ability of an individual to record sensory stimuli, events and information; retain them over short or long periods of time and recall the same at a later date when needed. Neurodegenerative disorders like Alzheimer's disease (AD), Parkinson disease (PD), depression, schizophrenia and others are associated with impairments in learning and memory (Jewart et al., 2005; Adewusi et al., 2010) characterized by disturbance of multiple cortical functions, including memory, judgment, comprehension, learning capacity and language, (Robert and Claudia, 1998). Poor memory, lower retention, and slow recall are common problems in today's stressful and competitive world, especially with associated ageing process evolving from malfunctioning of different biochemical pathways. 
The drugs currently available in market for the treatment of various learning and memory disorders are associated with several side effects, indicating need of substitute medication from alternative system of medicine (Schneider, 2001). Some medicinal plants have been used for decades in different cultures to improve memory and ameliorate aging effects such as; Lycium barbarum $\mathrm{L}$ (China), Corydalis spp (Denmark) and Melissa officinalis (Iran) (Akhondzadeh et al., 2003; Yu et al., 2005; Adsersen et al., 2006). In Nigeria, the Yoruba traditional medicine offers a number of safe treatments for central nervous system related disorders such as anxiety, aging and memory loss.

Quite a number of Yoruba traditional remedies for the treatment of age related cognitive disorders and other diseases have been recorded. Fatumbi, 1995, who spent many years living with natives and studying medicinal herbs. Elufioye et al., (2012) reported some plants used for memory enhancement and antiageing in Sagamu, Nigeria. Cyril-Olutayo et al., (2012) also reported some of the plants used as memory enhancer and antiageing in Ondo State, Nigeria. Many prescriptions and recommendations that claim to prevent or restore cognitive and memory deficits have not shown any actions in established test systems. Moreover, just a small number of herbs traditionally used for the CNS disorders have been gathered and evaluated pharmacologically regarding their mechanism of actions in terms of our modern understanding of brain functions.
Therefore, this work aimed at documenting plant species locally used for memory enhancement by the people of Ondo, Ekiti and Osun States of Nigeria mainly inhabited by the Yoruba tribe to enhance the previously documented species in South west states for scientific validation. This would serve as information for further research to assess the evidence of the efficacy of the various plants locally attributed to memory enhancers. The active ingredient that may improve brain function may attract sufficient research in the regard to juxtapose their potential effectiveness for the treatment of neurodegenerative diseases.

\section{MATERIALS AND METHODS}

\section{Study area}

Ethnobotanical survey was conducted in three different States of Southwest Nigeria; Ondo State, Ekiti State and Osun State (Fig. 1). Ekiti State comprises of Oja Oba market in Ado Ekiti of Ekiti State Ikoro Ekiti, Ijero; Osun State (Ikeji Ile of Oriade local government and Ilesha) and Akure town of Ondo State comprising the Oja Oba Market and Federal University of Technology Akure (FUTA) Campus. The three states are primarily agricultural states having many rural areas largely of subsistence farmers and peasant fishermen. The indigenous people of the states peak same Yoruba language although many of them identified as student can speak both Yoruba and English languages.

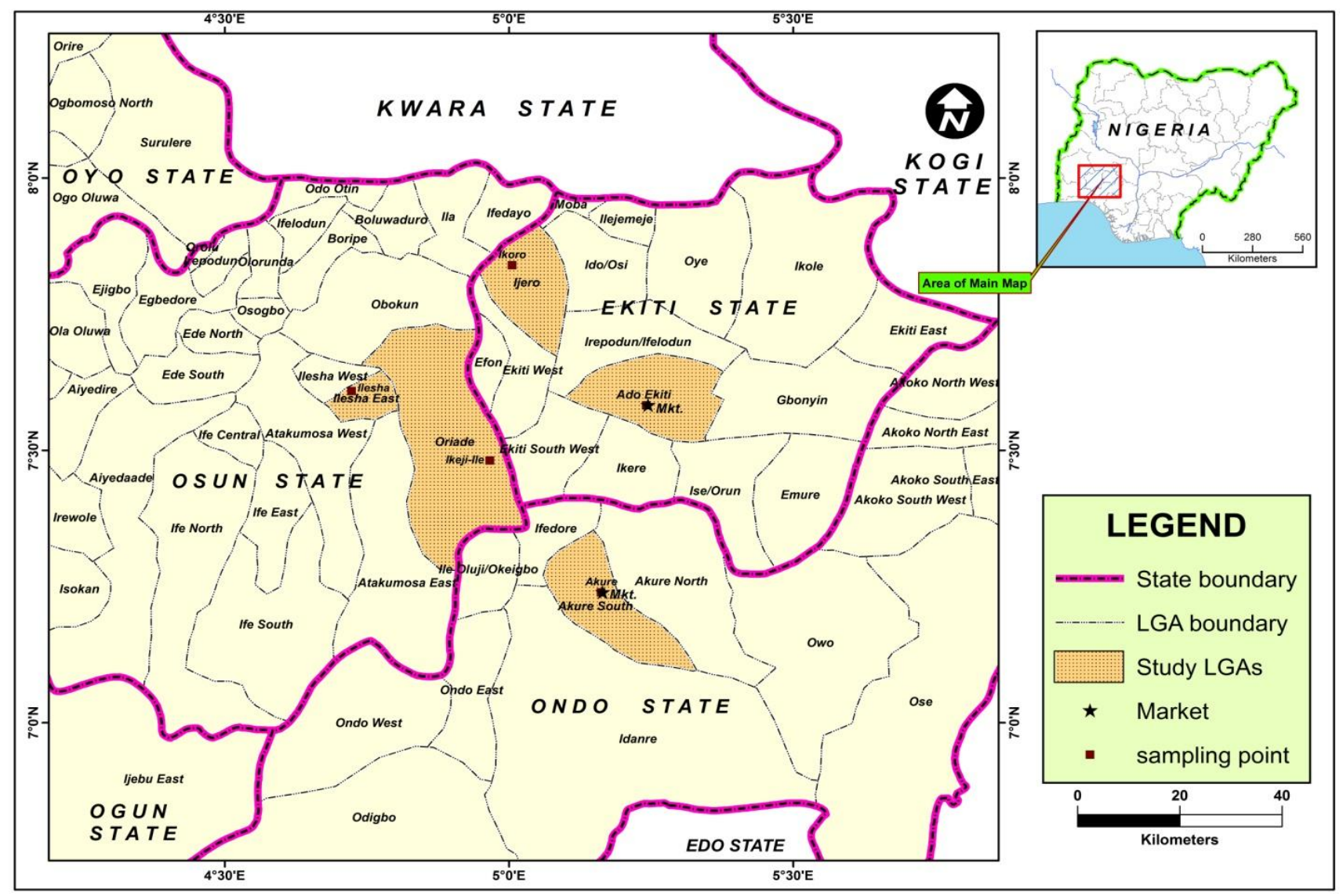

Fig. 1: Map showing Studied Local Government Areas of Nigeria. 


\section{Data collection}

Samples were collected between August 2013 and March 2014 at various locations of the three States. A combination of social survey, direct field observations comprising literatures, through friends, internets and semi structured questionnaires administered among the local herb vendors, traditional medicine practitioners (TMPs), artisans and students in higher institutions with a view to determine the utilization of medicinal plants for memory enhancement were used in this study. Following the methods of (Cyril-Olutayo et al., 2012 and Elufioye et al., 2012), the structured questionnaire was prepared in English language and discussion with most of the respondents was conducted in Yoruba language. The respondents were enlightened on the purpose of the interview and their consent to publish the findings obtained was sought before questioning. After some explanations to the herb vendors, the anonymous questionnaires were given to be filled by those who could. Where not, they were filled by the author through a non-oriented conversation. Information gathered during the conversation was transferred to a structured form in the questionnaire and samples were bought from the herb vendors before dishing out details of their knowledge. A total of 260 respondents were randomly interviewed in the three State including Ekiti State, Ondo State and Osun State. Plant specimens were collected and identified at the herbarium of Botany Department of Ekiti State University, Ado Ekiti, where specimens were deposited.

\section{RESULTS}

Figure 1 shows the detailed map of the study area comprising of Ekiti, Ondo \& Osun State of Southwestern Nigeria. Table 1 shows the demographic features of the respondents.

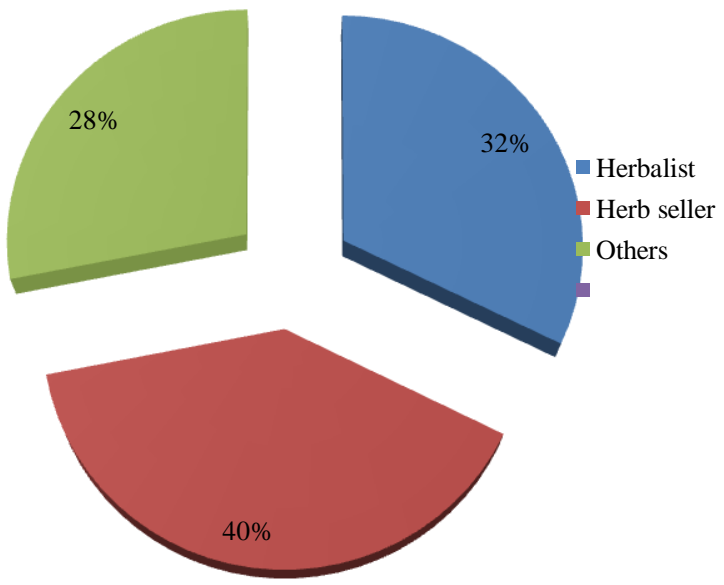

Fig.2: Occupation Distribution of the Respondents Across Three States Of Nigeria
A total number of 260 respondents were interviewed in the course of this research across the three States. The total population of the respondents was made up of the herbalists (32\%), herb sellers (40\%) and "other occupations" which comprised of the students and artisans (28\%). Out of these, $55.4 \%$ were males and $44.6 \%$ were females, their ages ranged from 10 to 75 years. About $71.2 \%$ of the respondents were married, $25 \%$ were single while others were elderly ones mostly above 70 years and those that have lost their spouse were $3.8 \%$.

Table 2 shows the list of plants locally used for memory enhancement. A total of thirty seven medicinal plants species belonging to twenty eight families (Table 2) were identified as plants locally used for memory enhancement among the three states.

Of all the plant species gathered, Bacopa floribunda and Scoparia dulcis belonging to the family Scrophulariaceae had high frequencies of 40 and 27 respectively. Other plant families of plant with appreciable frequency includes Parquetina nigrescen of Asclepiadaceae also (27); Aframomum melegueta (20) of Zingiberaceae; Cordia millenii (30) of Boraginaceae; Spondias mombin (25) of Anacardiaceae; Cola acuminate (24) of Sterculiaceae and Elaeis guineensis, Palmae (16). Among the plant species, trees are the predominant habit of the plants indicated (Fig. 3).

The medicinal uses are varied and the plant species parts used range from leaves, roots, stems, barks to fruits, or a combination of two or more in a species or with those of other species, but the predominant parts used are the leaves. Table 3 revealed the peculiarity in the suffix of the syllables of the local names (in Yoruba language) of some plants used for memory enhancement which are linked to notions of memory and intelligence.

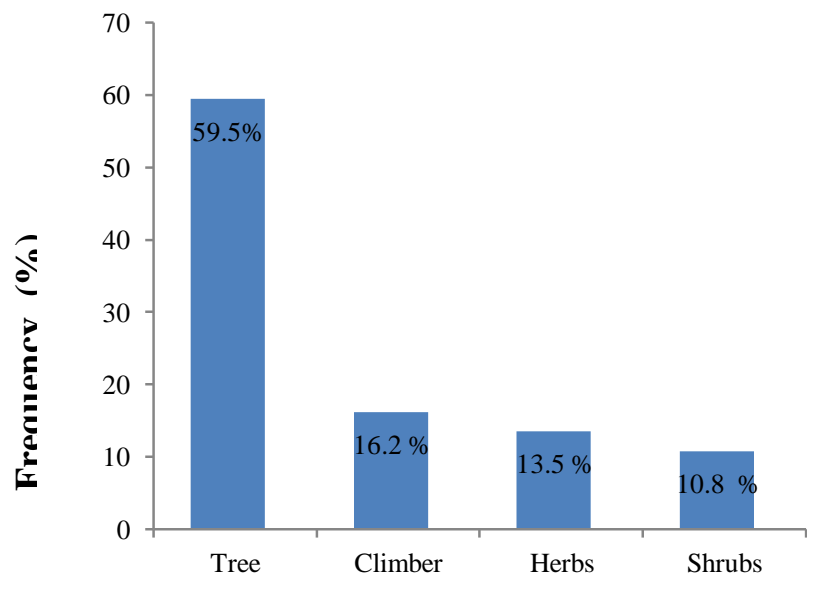

Plants habit

Fig. 3: Habit of plants used as memory enhancer. 
Table 1: Demographic Features of Ethnobotanical Respondents.

\begin{tabular}{|c|c|c|c|c|c|c|c|c|}
\hline \multicolumn{2}{|c|}{ Osun State } & \multicolumn{2}{|r|}{ Ekiti State } & \multicolumn{2}{|c|}{ Ondo State } & \multicolumn{2}{|c|}{ Total } & \multirow[b]{2}{*}{$\%$} \\
\hline & Frequency & $\%$ & Frequency & $\%$ & Frequency & $\%$ & Frequency & \\
\hline \multicolumn{9}{|l|}{ Gender } \\
\hline Male & 27 & 38.6 & 65 & 59.1 & 52 & 65 & 144 & 55.4 \\
\hline Female & 43 & 61.4 & 45 & 40.9 & 28 & 35 & 116 & 44.6 \\
\hline Total & 70 & 100 & 110 & 100 & 80 & 100 & 260 & 100 \\
\hline \multicolumn{9}{|c|}{ Age (years) } \\
\hline $10-30$ & 13 & 18.5 & 10 & 9.1 & 19 & 23.8 & 42 & 16.1 \\
\hline $31-50$ & 40 & 57.1 & 79 & 71.8 & 36 & 45.0 & 155 & 59.6 \\
\hline $51-70$ & 15 & 21.4 & 16 & 14.6 & 25 & 31.2 & 56 & 21.5 \\
\hline Above 70 & 2 & 2.9 & 5 & 4.5 & - & & 7 & 2.7 \\
\hline Total & $\mathbf{7 0}$ & 100 & 110 & 100 & 80 & 100 & 260 & 100 \\
\hline \multicolumn{9}{|c|}{ Marital Status } \\
\hline Married & 46 & 65.7 & 85 & 77.2 & 54 & 67.5 & 185 & 71.2 \\
\hline Single & 22 & 31.4 & 21 & 19.1 & 22 & 27.5 & 65 & 25.0 \\
\hline Others & 2 & 2.9 & 4 & 3.6 & 4 & 15 & 10 & 3.8 \\
\hline Total & 70 & 100 & 110 & 100 & 80 & 100 & 260 & 100 \\
\hline
\end{tabular}

Table 2: Plants Locally Used for Memory Enhancement.

\begin{tabular}{|c|c|c|c|c|c|c|}
\hline $\mathbf{S} / \mathbf{N}$ & Name & Family & Local Name & Habit & Part Used & Freq \\
\hline 1 & Abrus precatorius & Fabaceae & Omisinmisin & Climber & Aerial part & 8 \\
\hline 2 & Adansonia digitata $\mathrm{Linn}$ & Bombacaceae & Oshe & Tree & Leaves and stem bark & 3 \\
\hline 3 & Aframoтит melegueta $\mathrm{K}$ Schum & Zingiberaceae & Atare & Herb & Seed & 20 \\
\hline 4 & Alstonia boonei De Wild & Apocynaceae & Ahun & Tree & Leaves & 4 \\
\hline 5 & Bacopa floribunda (R.Br)Wettst & Scrophuliaceae & Ewe Oniyemuye & Herb & Aerial parts & 40 \\
\hline 6 & Bambusa vulgaris Schrad. ex J.C. Wendl & Poaceae & Oparun & Shrub & Young leaves & 4 \\
\hline 7 & Baphia nitida Lodd. & Papilinionaceae & Owiwi, Iyereosun & Shrub & $\begin{array}{l}\text { Leaves, stem bark, wood } \\
\text { and root }\end{array}$ & 2 \\
\hline 8 & Carica papaya Linn & Caricaceae & Ibepe & Tree & Leaves and root & 7 \\
\hline 9 & Chrysophylum welwitschii & Sapotaceae & Asiyele & Climber & Leaf & 1 \\
\hline 10 & Cocos nucifera Linn & Palmae & Agbon & Tree & Roots & 4 \\
\hline 11 & Cola acuminata (P. Beav) Schott and End & Sterculiaceae & Obi abata & Tree & Seeds & 24 \\
\hline 12 & Cordia millenii Bak. & Boraginaceae & Omoh & Tree & Stem bark & 30 \\
\hline 13 & Crossopteryx febrifuga (Afzel.) Benth & Rubiaceae & Ayeye & Tree & Bark & 3 \\
\hline 14 & Detarium microcarpum Guill. \&Perr. & Caesalpiniaceae & Ariran & Tree & Stem and leaves & 12 \\
\hline 15 & Dichapetlum toxicarium Bail (G.Don) & Dichapetalaceae & Itakun & Woody Climber & Leaf and twigs & 3 \\
\hline 16 & Dioscorea mangenotiana J. Miège & Dioscoreaceae & Esusu & Climber & Leaves & 4 \\
\hline 17 & Elaeis guineensis Jacq. & Palmae & Ope & Tree & Young leaves & 16 \\
\hline 18 & Ficus exasperate Vahl & Moraceae & Ipin & Tree & Leaves & 5 \\
\hline 19 & Garcinia kola Heckel & Gutiferae & Orogbo & Tree & Seed & 9 \\
\hline 20 & Harungana madagascariensis Lam. ex Poir & $\begin{array}{l}\text { Harungaceae/ } \\
\text { Clusiaceae }\end{array}$ & Arunje, Asunje & Tree & Leaves & 4 \\
\hline 21 & Khaya ivorensis A. Chev & Meliaceae & Oganwo & Tree & Stem and root bark & 1 \\
\hline 22 & Lophira alata Banks ex Gaertn. f & Ochnaceae & Eki & Tree & $\begin{array}{l}\text { Seed, root, leaves and stem } \\
\text { bark }\end{array}$ & 2 \\
\hline 23 & Moringa oleifera Lam. & Moringaceae & Ewe moloye & Tree & leaves & 1 \\
\hline 24 & Montandra guineensis L & Apocynaceae & Asifirin & Tree & Roots & 1 \\
\hline 25 & Musa sapientum Linn & Musaceae & Ogedewewe & Tree & Stem & 18 \\
\hline 26 & Parquetina nigrescen Baillon. & Asclepiadaceae & Ogbo & Climber & Stem, Leaves & 27 \\
\hline 27 & Picralima nitida Stapf Th. \& H. Dur & Apocynaceae & Abeere & Tree & Fruits and seeds & 3 \\
\hline 28 & Quassia undulata (Guill. \&Perr.) D.Dietr. & Simaroubaceae & Oriji & Tree & Leaves & 2 \\
\hline 29 & Scoparia dulcis $L$ & Scrophulariaceae & $\begin{array}{l}\text { Olomuyinrin, } \\
\text { Oyin-gogoro }\end{array}$ & Shrub & Leaves & 27 \\
\hline 30 & Senecio abyssinicus A.Rich & Asteraceae & Amunimuye & Herb & Aerial parts & 13 \\
\hline 31 & Solanum incanum $\mathrm{L}$ & Solanaceae & Ikan, Igba & Herb & Leaves, fruits and roots & 3 \\
\hline 32 & Spondias mombin $\mathrm{L}$ & Anacardiaceae & $\begin{array}{l}\text { Iyeye, } \\
\text { Ekikan }\end{array}$ & Tree & Leaves & 25 \\
\hline 33 & Tectona grandis $\mathrm{L}$ & Verbanaceae & Agala & Tree & Young leaves & 1 \\
\hline 34 & $\begin{array}{l}\text { Tetrapleura tetraptera (Schumm. \&Thonn.) } \\
\text { Taub }\end{array}$ & Mimosaceae & Aridan & Tree & Fruits & 2 \\
\hline 35 & Thaumatococcus daniellii (Benn.) Benth & Marantaceae & Eeran & Rhizome & Leaf & 5 \\
\hline 36 & Uraria picta (Jacq.) DC & $\begin{array}{l}\text { Leguminosae- } \\
\text { Papilionoideae }\end{array}$ & Alupayida & Climber & Leaves & 7 \\
\hline 37 & Zea mays Linn & Poaceae & Agbado & Shrub & Leaves & 3 \\
\hline
\end{tabular}


Table 3: Suffix of Plants Name In Relation to their Syllabic Meaning.

\begin{tabular}{|c|c|c|}
\hline Suffix Of Plant Name (Yoruba Language) & Meaning & Reference Plant \\
\hline As/iye/le & In which we understand & Chrysophylum welwitschii \\
\hline A/ye/ & Makes one understand & Crossopteryx febrifuga \\
\hline /Iye/ & Memory & Spondias mombin \\
\hline /Iye/ye & To understand and live & Spondias Mombin \\
\hline /Iye/ Ataare & Memory alligator pepper & Aframomum melegueta \\
\hline Ko/oye/jo & Focus memory & Not identified \\
\hline Oniye/n/iye/ & Master of knowledge & Bacopa floribunda \\
\hline /Oye/ & Understanding & Not identified \\
\hline /Ye/ye/ & Understand & Spondias mombin \\
\hline Abo /imo/ & Female wisdom & Elaeis guinensis \\
\hline Eemo & That sticks in one memory & Not identified \\
\hline Imo ope & Knowledge palm tree & Elaeis guinensis \\
\hline /Omo/ & Knowledge & Cordia milleni \\
\hline Alaran & Reminds & Not identified \\
\hline Aparan & To beat to remember & Not identified \\
\hline Eeran & Remembrance & Thaumatococcus daniellii \\
\hline Eeran esin & Memory like of a horse & Not identified \\
\hline Iran & Remembrance & Thaumatococcus daniellii \\
\hline Ogbo & You hear. & Parquetina nigrescen \\
\hline
\end{tabular}

\section{DISCUSSION}

In our effort to document the medicinal plants used for memory enhancement in Southwestern Nigeria, table 1 reflects that across the states, that the males $(55.4 \%)$ participated were more aware about the use of memory enhancing plants than the females (44.6\%). Oyelakin, (2009) reported that among the Yoruba ethnic group of Nigeria, traditional medicine practice is dominated by males due to secrecy in transmitting the knowledge from generation to generation. This was not different from the report that males are culturally seen as the heirs of family heritage for preservation and continuity with the belief that females leave the family after marriage (Elufioye et al., 2012).

The result (Fig.1) also showed that the artisans and students which are within category of "other occupation" (28\%) are less informed about plants used for memory enhancement across the study areas when compare with the herbal practitioners. Also, majority of the middle aged people (31-50) and the elderly ones (51-70), mostly all married (71.2\%) were more knowledgeable about traditional medical practice than the younger ones. This is an indication that our indigenous traditional practice is not totally lost among the younger generations. Although there were comments and reports from the respondents of loss of interest in TMP and that there exists an expanding information gap between the older generations and the younger due to differences in lifestyle and career preferences and urban migration therefore leading to unavailability for receiving information (Olatunji et al., 2014, Ogumefun et al., 2015).

Due to the specificity of the objective of this survey, observations gathered from this survey revealed that the knowledge of most of the respondents were inclined more to other forms of herbal medicine like pediatrics, sexually transmitted diseases, food supplements and so on, which this study did not cover. This might be the reason for the discrete number of plants gathered which invariably results to not much variability in the knowledge of the respondents about the mentioned plants used for this purpose among individuals across the three states. The reason may also be that there is a kind of networking in form of knowledge sharing among the TMP across the region covered. Bacopa floribunda belonging to family Scrophulariaceae was found to be mostly mentioned among of the memory enhancing plants. The species Bacopa monniera and B. floribunda have been reported in Ayurvedic medicine and in traditional treatments for a number of disorders, particularly those involving anxiety, intellect, and poor memory (Cyril-Olutayo et al., 2012, Sigh and Dhawan, 1997). Several other works have established the use of Bacopa species and other plants as memory enhancers (Sigh et al., 2010, Sudharani et al., 2011, Deval et al., 2011). Almost the same importance was placed on Scoparia dulcis which also belongs to the same family Scrophulariaceae. It was mentioned to be very useful for memory enhancement among Yoruba speaking parts of Nigeria different from this present study area (Cyril-Olutayo et al., 2012, Elufioye et al., 2012). The plant has been reported to show a markedly protective role against lipid peroxidation induced in brain and erythrocytes (Ahmed et al., 2011).

It was also gathered from the field and literature that the plants that stimulate the mind have a peculiarity in the suffix of the syllables of their names (Table 3) which were linked to notions of memory and intelligence. Stimulants belong to different kinds and grades, ranging from mental stimulants 'Isoye' to stimulant of virility, 'aremo', and body stimulants, 'marale or mu ara le', all interpreted in Yoruba language (Fatumbi, 1995). There are also stimulants which are able to make people crazy, antidotes that protect against craziness and remedies that cure craziness. Other stimulants includes those linked to notions of memory and intelligence: 'ye', to understand (recipe from Spondias mombin, Bacopa floribunda), 'mo', to know 'ran or ranti', to remember, 'gbo', to hear, (recipe from Perquitenia nigeriscence) 'gbon', to be wise among which majority of the plants listed in Table 2 belongs. The fact that many of the practitioners could not explain why in many cases two or more plants or plant parts are used jointly makes it difficult to be sure which plant or part actually 
responsible for the memory enhancement. According to the respondents, the challenge faced is that many of these plant species are being sourced from the wild and they are becoming scarce as a result of over exploitation, urbanization and industrialization of these areas. Soladoye et al., 2006, recommended that the vulnerability of medicinal plants to over exploitation and extinction needs to be dealt with seriously. Issues relating to the conservation of these medicinal plants should be addressed by the government and non-governmental organizations. Conservation methods such as In-Situ and Ex-Situ should also be adopted to protect our natural biodiversity.

\section{CONCLUSION}

This study has revealed that ethno-medicinal practices are well accepted by the people of the mentioned areas. Information made available by the respondents revealed that the use of these plants for the purpose of memory enhancement are limited in number but preserved and unaltered as inherited from their forefathers and may likely continue to remain in the future if properly documented and conserved. It is suggested that an enduring and sustainable conservation efforts be put in place by the community and government to safeguard these important medicinal plants as no curiosity to know about more of these kinds of rare plants. Although the acclaimed properties of these plants cannot be scientifically verified there is need to validate the traditional believe in the use of the plants for brain enhancement (Oogun Isoye). As a matter of fact, if the plants really have enhancement effect on a normal person especially adult, it should definitely have a positive effect on a person suffering from cognitive disease like Parkinson disease or Alzeimer disease.

\section{Financial support and sponsorship: Nil.}

Conflict of Interests: There are no conflicts of interest.

\section{REFERENCES}

Adewusi EA, Moodley, N, Steenkamp, V. Medicinal plants with cholinesterase inhibitory activity: A Review. African Journal of Biotechnology, 2010; 9(49), 8257-8276.

Adsersen A, Gauguin B, Gudiksen L, Jager AK. Screening of plants used in Danish folk medicine to treat memory dysfunction for acetylcholinesterase inhibitory activity. J. Ethnopharmacol., 2006; 104, 418-422.

Ahmed YC, Pierre AED, Sombie AT, Martin K, Moussa MY Compaore and Odile GN Protective Effect of Scoparia dulcis on Brain and Erythrocytes. Current Research Journal of Biological Sciences, 2011;3(3): 254-261.

Akhondzadeh S and Noroozian M. Alzheimer's disease: pathophysiology and pharmacotherapy. Drugs, 2002; 4, 1167-1172.

Cyril-olutayo CM, Oladele AT and Elufioye TO. Ethnobotanical survey of plants Used as Memory Enhancer and Antiaging in Ondo State, Nigeria. International Journal of Pharmacy, 2012; 2(1): 2632.

Deval K, Vaibhav S, Krishna KL. Effect of Bacopa on Memory Deficit Produced by Chronic Administration of Topiramatein Rats. International Journal of Pharmacy, 2011.; 1(2): 118-24.
Elufioye TO Oladele AT, Cyril-olutayo CM, Agbedahunsi JM and Adesanya SA. Ethnomedicinal study and screening of plants used for memory enhancement and antiaging in Sagamu, Nigeria. European Journal of Medicinal Plants, 2012; 2(3): 262-275. Science Domain International.

Fatumbi VP. Ewe: The use of plants in Yoruba Society. Editora Schwarcz LTDA, Sao Paulo 1995.

Jewart RD, Green J, Lu CJ, Cellar J, Tune LE. Cognitive, behavioral, and physiological changes in Alzheimer disease patients as a function of incontinence medications. Am J Geriatr Psychiatry, 2005;13, 324-328.

Lawal IO, Grierson DS a nd Afolayan AJ. Phytotherapeutic Information on Plants Used for the Treatment of Tuberculosis i n Eastern Cape Province, South Africa. Evidence-Based Complementary and Alternative Medicine, 2014, Article ID 735423, 11 pages.

Ogunmefun OT, Olatunji BP and Adarabioyo MI. Ethno medicinal Survey on the Uses of Mistletoe in South-Western Nigeria. European Journal of Medicinal Plants, 2015; 8(4): 224-230, 2015.

Olatunji BP, Ajibola DO, Adebayo EO, Nyong EE and Moody JO. Ethnomedicinal Survey of Botanicals Used by Herbal Practitioners in Yagba East Local Government of Kogi State, Nigeria. European Journal of Medicinal Plants, 2014; 4(12): 1479-1488.

Oyelakin RT. Yoruba traditional medicine and the challenge of integration. The Journal of Pan African studies, 2009; 3(3).

Robert, K., Claudia, K. (1998). Risk factors for Alzheimer's disease. Neuro Science News, 1, 27-44.

Schneider LJ. Treatment of Alzheimer's disease with cholinesterase inhibitors. Clin. Geriatr. 2001; Med. 17, 337-339.

Singh AK, Gupta A, Mishra AK, Gupta V, Bansal P, Kumar S. Medicinal Plant for Curing Alzheimer's disease. Int. J. Pharm. Biol. Arch., 2010;1(2):108-14.

Singh HK,Dhawan BN. Neuropsychopharmacological effects of the Ayurvedicnootropic Bacopa monniera Linn. (Brahmi). Indian J. Pharmacol., 1997; 29: 359-65.

Soladoye MO, Amusa NA, Salmot ORE, Emmanuel CC and Ayanbamiji, AT. Ethnobotanical Survey of Anti-Cancer Plants in Ogun State, Nigeria. Annals of Biological Research, 2010; 1 (4): 261-273.

Soladoye MO, Yakubu FA, Kola-Oladiji K, Alabi DA \& Agbomeji YO. The Collection, Conservation and Cultivation of Local Medicinal Plants for Natural Medicine Production. Paper presented at the Seminar/Workshop and Exhibition of Natural Medicine Products. Organized by Nigeria Traditional Medical Association, Ijebu-North in Collaboration with Faculty of Science, Olabisi Onabanjo University AgpIwoye, held 19-23 September, 2006

Sudharani D, Krishna KL, Deval K, Safia AK. Pharmacological Profiles of Bacopa monniera : A Review. International Journal of Pharmacy, 2011; 1(1):15-23.

Yu M, Sarana KL, Sau-Wan L, Chi-Ming C, Sze-Yong Z, Kwok-Fai S, Wai-Hung Y, Raymond CC. Neuroprotective effects of antiaging oriental medicine Lycium barbarum against b-amyloid peptide neurotoxicity. Experimental Gerontology 2005; 40, 716-727.

\section{How to cite this article:}

Babawale OP, Taiwo F, Adetunj OS. Ethnobotanical Survey of Plants Used as Memory Enhancer in Three States of Southwestern Nigeria. J App Pharm Sci, 2016; 6 (09): 209-214. 